\title{
Etulo Verb Structure
}

\author{
Adaobi Ngozi OKOYE \\ Department of Linguistics \\ Faculty of Arts \\ Nnamdi Azikiwe University \\ PMB5025 Awka \\ Nigeria
}

\begin{abstract}
This paper examines the structure of the verb in Etulo, a Benue Congo language spoken by a minority group in Benue State, Nigeria. It seeks to accounts for the phonological and morphological structures of the verb. Data collection is mainly based on elicitation from Etulo native speakers resident in Adi.The study adopts a descriptive approach in the analysis of the collected data. From the data analyzed, the study discovers that phonologically, Etulo verbs attest three syllable patterns. In terms of their morphology, the verbs fall into simple and complex verbs. The study further observed that some complex verbs display variable meanings. The study adds to existing literature on the verb structure of African languages and concludes that the structure of the verb in Etulo aligns with the structure attested for Benue Congo languages.
\end{abstract}

Keywords: Verb Structure, Syllable, Phonology, Morphology and African Language

\subsection{Introduction}

The verb is an important category that should be investigated for a proper description of the structure of languages. This is in consonance with the observation by Palmer (1965:1) that learning a language is (to a very large extent) learning how to operate the verbal forms of the language. Payne (2006:104) opines that verbs produce changes in the world in addition to expressing conceptual categories such as Tense/ Aspect/Mode (TAM).It is observed from studies on the verb in other languages that verbs play a central role in sentence construction and comprehension. Thus, the relevance of the verb in a language makes it possible for it to be used in isolation with an reasonable conveyance of meaning. The verb also signifies an activity or process performed or undergone. In addition, the verb is the central part of predication, hence its crucial semantic role in the sentence.

This paper provides an account of the phonological and morphological structure of the Etulo verb. Etulo belongs to the Idomoid group of the West Benue Congo of Niger Congo group of languages. (Gordon, 2005). Etulo refers simultaneously to both the language and the ethnic group. The Etulo are found in Benue and Taraba States, Nigeria. The Etulo speakers in Benue are found in Adi, Buruku Local Government Area and parts of Kastina-Ala, Kastina Ala Local Government Area. The data for this work were elicited from Etulo native speakers. The language under investigation is a tone language, with high, low, downstep and gliding tones (Ezenwafor and Mmadike 2012:618). This study adopts Green and Igwe's (1963) tone marking convention. Following this convention, low tone is indicated with a grave accent [.], step tone is marked with a macron $[-]$, the gliding tone is marked with a modifier letter up arrowhead $[\wedge]$ while, the high tone is left unmarked.

The paper comprises five sections. Section one is the introduction while section two reviews some literature relevant to the present study. In sections three and four, the syllables as well as the morphological structures of the verb in Etulo are presented and analyzed. Section five summarizes and concludes the study.

\subsection{Literature Review}

The verbs in human language have been studied from various perspectives. We shall examine some studies particularly those carried out on African languages adopting the descriptive approach. Welmers (1973) and Childs (2003) have carried out a survey of African language structure bringing to bear, the features which are pervasive in different aspects of the languages of Africa. This study lends support to these earlier studies.

Child (2003) observes that verbs in African languages exhibit complexity with respects to the number of arguments allowed as subjects, syntactic status as well as the ordering of arguments. According to him, a semantically ditransitive verb, 'give' and 'send' allow two postverbal unmarked arguments. He exemplifies this based on data from Igbo and Fula languages shown below: 


\section{1a.Igbo: Musa de - e -re Fatima leta \\ Musa write - Goal-Aspect Fatima letter \\ Musa wrote Fatima a letter}

\section{b. Fula: Musa wind -an -i Fatima patakeewol \\ Musa write -goal - Aspect Fatima letter \\ Musa wrote Fatima a letter}

Culled from Child (2003:125)

We observe that there are two arguments after the Igbo verb de 'write' and the Fula verb wind 'write'. The arguments Fatima and leta in example 1a and Fatima and patakeewol in example 1b demonstrate that the verbs are ditransitive , since they take two arguments.

Yuka and Omoregbe (2010) examine the internal structure of Edo verbs. The aim of their study was to account for the morphology of Edo verbs. The study submits that two verb types can be confirmed in Edo, namely the basic verb form and the complex verb form. The latter form comprises verbs with $\mathrm{V}+\mathrm{V}, \mathrm{V}+\mathrm{N}, \mathrm{V}+\mathrm{N}+\mathrm{N}$ and $\mathrm{V}+$ extension syllable structure while the former verb form consists of verbs with either CV or CVCV syllable structure. Instances of the basic verbs in Edo culled from the authors are shown below

2a. gbè 'to dance'

b. sàà ' to burst'

c.dìguẹ ' to kneel'

The verb in example (2a) has CV syllable structure; (2b) is a case of CVV while example (2c) has a CVCV structure. Yuka and Omoregbe further state that the feature specifications of some Edo verbs do not conform to Chomsky's [+V$\mathrm{N}]$ universal specification for verbs. Chomsky's universal categorial distinction according to them assumes that a verb is void of any nominal trait. However, they observe that some Edo verbs have a combination that are not void of nominal traits yet the native speakers interpretation of such strings depicts a verb. They buttress their point with the examples in

$\begin{array}{cccc}\begin{array}{c}\mathrm{V} \\ \begin{array}{c}\text { 3a khòo } \\ \text { to fight }\end{array}\end{array} & \begin{array}{c}\mathrm{V} \\ \text { mié } \\ \text { to see }\end{array} & \begin{array}{c}\mathrm{N} \\ \text { òtò } \\ \text { ground }\end{array} & \begin{array}{r}\text { khọnmioto } \\ \text { to be victorious }\end{array} \\ \begin{array}{c}\text { b.rhiò } \\ \text { to rise }\end{array} & \begin{array}{c}\text { kpàá } \\ \text { to lift }\end{array} & \begin{array}{c}\text { egbe } \\ \text { body }\end{array} & \begin{array}{r}\text { rhiọ̀kpègbé } \\ \text { to resurrect }\end{array}\end{array}$

The authors note that the deep structure of the verbs (in 3a and b) negates Chomsky's universal [+V-N] specification for verbs.

Mbagwu (2013) examines locatum and location verbs in Igbo with the aim of determining the morphological features, role assignment to NP and the case assigned to NPs that co-occur in sentences of these verbs. The study was done within the Government and Binding theoretical framework. The findings of the study show that locatum verbs are marked by suppressive locative affixes while location verbs are marked by the illative locative affix, which is an affix that indicates movement into something. The author further observes that the argument structure of such a verb is (AGENT, THEME) where the subject is assigned the agent role while the object is assigned the theme role. Mbagwu distinguishes locatum from location verbs following Kiparsky's (1997) formalization rule which posits that locatum verbs express terminal coincidence as opposed to location verbs that express central coincidence. The author correlates Kiparsky's claim of terminal coincidence for locatum verbs using the following Igbo verbs.

$\begin{array}{ccc}\text { 4a dó } & \text { ídō } & \text { 'to place' } \\ \text { b kò } & \text { íkō } & \text { 'to hang' } \\ \text { c ghá } & \text { íghā } & \text { 'to spread' } \\ \text { d mákù ímákū } & \text { 'to embrace' } \\ \text { e sú } & \text { ísū (ộnù }) & \text { 'to kiss' }\end{array}$

These verbs are used in the examples below
5a Obi mákụ̀ù̀
Ada
Obi leap.against-pst Ada
Obi embraced Ada.

b Ada sùrù Obi ọnụ

Ada punch pst Obi mouth 
Ada kissed Obi.

culled from Mbagwu (2013:61)

The interlinear glossing provided by the author with regard to the verb sùrù in (5b)as 'punch pst' is not acceptable to the researcher, as it appears to depart from the fact that some Igbo verbs need complements to achieve meaning . Sú happens to belong to this group of verbs as evidenced in its co-occurrence with different noun complements in the instances below

6a. sú ộnụ 'kiss'

b. sú okpọ 'hit blow'

c. sú ákā ' hit with intensity

With regard to the location verbs, the author claims that this class is delineated by emphasis on the location into which an entity is moved in contrast to locatum, which focuses on the entity that is located. His examples of location verbs include

7a. tìnyé ítínyē 'to put into'

b. rù̀nye írùnyè 'to push in'

c. bànyé íbànyè 'to soak in' a liquid

d. wụ̀nyé íwứnyē 'to pour into'

e. dànyé ídànyè 'to fall into'

These verbs are used in the examples shown below:

8a. Obi tìnyèrè ikó n'ìtè

Obi put ILL-pst cup in pot

Obi put a cup into a pot

b. $\mathrm{O}$ dànyèrè n'àkpà

3CL fall-ILL-pst in bag

She fell into a bag

culled from Mbagwu (2013: 63)

Agbo and Yuka (2011) account for transitivity in Igbo adopting the transitivity hypothesis explored in Hopper and Thompson (1980). The study employed seven out of the ten components of transitivity in examining the transitivity of five classes of Igbo verbs namely: general complement verbs, inherent complement verbs, prepositional phrase complement verbs, bound complement verbs and ergative complement verbs. The authors claim that prepositional complement verbs have agents that lack the features of volitionality. They exemplify as follows

9a. Ha kwu-ru n'efu

3Pl speak-IND in emptiness

They spoke nonsense

b. Ha me-re na-nkiti

3PL do-IND in vain

They acted in vain

(Agbo and Yuka 2011: 39-40)

The present study disagrees with the claim that the agent ha '3PL' in the expressions in (9a) and (b), lack volitionality. The submission of this study is that the agents are volitional actors with actions that eventually resulted in unproductivity. Section 3.0 following, accounts for the syllable structure of Etulo verbs

\subsection{The syllable structure of Etulo verbs}

The basic structure of the Etulo clause is SVO. The Etulo verb consists of a verb stem in combination with other optional constituents. The following syllable types are attested in Etulo:

a.Monosyllabic verbs with CV structure

b.Disyllabic verbs which have $\mathrm{CV}-\mathrm{CV}$ and $\mathrm{N}-\mathrm{CV}$

c. Trisyllabic verbs with CV-CV-V and CV-CV-CVstructures

\subsection{Monosyllabic Verbs}

This syllable structure constitutes an onset and a nucleus without a coda. The onset is usually a consonant while the nucleus is a vowel. The nucleus bears the tone that is either a high or a low tone. 
Etulo monosyllabic verbs are illustrated with the following examples
10a. tsà 'knock'
b.tsò 'teach'
c. so 'pound'
d. sa 'wash'
$\mathrm{CV}$
$\mathrm{CV}$
CV
$\mathrm{CV}$
e. tò 'dig'
f. wa 'drink'
CV
CV
CV
gnyà 'tell'
h. nu 'give'

The Etulo verbs in (10a-h) have a CV structure, which comprises an onset, a nucleus and no coda; hence, the syllable structure is said to be open. The verb tsà 'knock' in a and tsò 'teach' in (b), so 'pound' in (c) and sa 'wash' in (d) are minimal pairs while (a, b and e) instantiate a minimal set differing only in the vowel segments. Examples (a, b, e and g) instantiate Etulo monosyllabic verbs with low tone while (c, $d, f$ and $h$ ) are monosyllabic verbs with high tone.

\subsection{Disyllabic Verbs}

The disyllabic verbs comprise the CV-CV and N-CV syllable structures. The disyllabic verbs allow a combination of the high, low ,step and gliding tones
3.2.1 CV-CV Type
11a. fa- wa 'tear' $\mathrm{CV}-\mathrm{CV}$ CV-CV
b.gbi-li 'scrub'
$\mathrm{CV}-\mathrm{CV}$
c.fu-lu 'fold'
d. pi-li 'rob' (of pomade)
e. kà-kà 'enter' $\mathrm{CV}-\mathrm{CV}$
f. gà-dò 'listen' $\mathrm{CV}-\mathrm{CV}$
g.bù-lù 'fly'
CV-CV CV-CV

\section{j. gbi-gbî 'bark'}
$\mathrm{CV}-\mathrm{CV}$
$\mathrm{CV}-\mathrm{CV}$
k. yì-do 'return' 1. ge-kغ̀ 'lean'
$\mathrm{CV}-\mathrm{CV}$

The Etulo disyllabic verbs with CV -CV structure in (11a-d) are high toned while (11e-g) are low toned. The verb kpa$y \overline{1}$ 'learn' in $(11 \mathrm{~h})$ comprises a high and step tones while the vowels of the disyllabic verbs in $(11 \mathrm{i}$ and $\mathrm{j})$ bear the high and rising-falling tones.

\subsubsection{N-CV Type}

Etulo verbs with N-CV structure begin with a syllabic nasal and end with a vowel. From the data collected for the present study, verbs with this syllable structure appear to be few in number. However, it is necessary that we point out their existence. Etulo N-CV verbs include
12a. m-be 'build',
b. m-bè 'swallow'
$\mathrm{N}-\mathrm{CV}$
$\mathrm{N}-\mathrm{CV}$
c. ̀̀-dzî 'bury'

\section{$\mathrm{N}-\mathrm{CV}$}

\subsubsection{Trisyllabic Verbs}

The verbs considered as trisyllabic in the present study have either a CV-CV-V structure or a CV-CV-CV structure. The trisyllabic verbs are shown in example 13
13a. kwu-lu-ū 'die'
b. ka-dze- $\bar{\varepsilon}$ 'crack'
$\mathrm{CV}-\mathrm{CV}-\mathrm{V}$
$\mathrm{CV}-\mathrm{CV}-\mathrm{V}$
c.fa-ti-la 'hang'
$\mathrm{CV}-\mathrm{CV}-\mathrm{CV}$

Table 1 Syllable pattern of Etulo verbs

Table 1 Syllable pattern of Etulo verbs

\begin{tabular}{|c|c|c|c|c|}
\hline Monosyllabic verbs & \multicolumn{2}{|c|}{ Disyllabic verbs } & \multicolumn{2}{|c|}{ Trisyllabic verbs } \\
\hline $\begin{array}{l}\text { di 'see' } \\
\text { CV }\end{array}$ & $\begin{array}{l}\text { fu-lu 'fold' } \\
\text { CV-CV }\end{array}$ & $\begin{array}{l}\text { m-be 'build' } \\
\text { N-CV }\end{array}$ & $\begin{array}{l}\text { kwu-lu-̄̄ 'die' } \\
\text { CV-CV-V }\end{array}$ & $\begin{array}{l}\text { fa-ti-la 'hang' } \\
\text { CV-CV-CV }\end{array}$ \\
\hline $\begin{array}{l}\text { nu 'give } \\
\mathrm{CV}\end{array}$ & $\begin{array}{l}\text { tu-kû 'close' } \\
\text { CV-CV }\end{array}$ & $\begin{array}{l}\text { m-bè 'swallow' } \\
\text { N-CV }\end{array}$ & $\begin{array}{l}\text { ka-dze- } \bar{\varepsilon} \text { 'crack' } \\
\text { CV-CV-V }\end{array}$ & \\
\hline $\begin{array}{l}\text { fo 'hear' } \\
\text { CV }\end{array}$ & $\begin{array}{l}\text { pi-tà 'search' } \\
\text { CV-CV }\end{array}$ & $\begin{array}{l}\text { n-dzi ‘bury’ } \\
\text { N-CV }\end{array}$ & & \\
\hline
\end{tabular}

Table 1 above shows the classification of Etulo verbs based on their syllable pattern.

\subsection{Morphological classification of Etulo Verbs}

Morphologically, Etulo verbs fall into either the simple verb class or the complex verb class.

\subsection{Simple Verbs}


The simple verbs comprise the monosyllabic verbs with a CV structure and the disyllabic verbs with either a CV-CV or an N-CV structure.

\subsubsection{Simple Monosyllabic Verbs}

Simple monosyllabic verbs with a CV structure are shown in the example 14 below

$\begin{array}{clll}\text { 14a. ba 'come' } & \text { b.di 'see' } & \text { c.kpà 'like' } & \text { d.fe 'flow' } \\ \text { e.nu 'give' } & \text { f.gya 'buy' } & \text { g.wo 'put' } & \text { h.gbò speak' } \\ \text { i.wa 'drink' } & \text { j. la 'live } & \text { k..fo 'hear' } & \text { l.dzè 'stay' }\end{array}$

The simple CV structure verbs in sentential constructs can occur with or without an object complement as shown in the examples in (15a-g):

15a.Èfu bā

Efu come

'Efu came'

b.Èyi di àbu

1PL see you

'We saw you'

c.Èfu kpà anî

Efu like 1SG

'I like Efu'

d.Èkyô fe ìkà lû

River flow axe go

'The river carried the axe'

e.Èfu nù anî àf $\varepsilon$

Efu give me letter

'Efu gave me a letter'

f.Ani kà lu Àdì

ISG fut go Adi

'I will go to Adi'

g.Èfu gyā āngwō

Efu buy yam

'Efu bought yam'

From the examples, the simple verb ba 'come' lacks an object complement in (15a.) In (15b, c, d, f and g) the verbs di 'see', kpa 'like', f $\varepsilon$ 'flow', lu 'go' and gya 'buy' occur with object complements In (15e), the simple verb nù 'give' has two object complements. As earlier pointed out, Etulo has SVO word order. However, the expression Ėfu kpà anî which translates as I like Efu' in (15c) demonstrates a hierarchy of argument in which the subject position is occupied by the Theme while the Experiencer occupies the object position. The same hierarchy of argument seems to apply to the Igbo expression Agwa na amasi m, 'I like beans'. However, this is different from what obtains in the English language where the subject is the Experiencer while the object corresponds to the Theme.

\subsubsection{Simple Disyllabic Verbs}

The simple disyllabic verbs comprise verbs with CV-CV and N-CV structures.

Some Etulo disyllabic simple verbs are shown in (16) below
16 a gbobū 'break'
b.bità 'ask'
c.kpayi 'learn'
d. fawa 'tear'
e. gekغ̀ 'lean'
f. bekè 'lean'
g.ǹdzì 'bury'
h. mbe 'build'

Some disyllabic verbs listed above are used in sentential constructs in (17a-g) below

$17 \mathrm{a}$. O bità iŷ̂ mgbi anî

3SG ask name POSS $1 \mathrm{SG}$

He asked me my name

b. Èfu fawā Àfè ànwutò wà

Efu tear Afe cloth perf

Efu has torn Afe's cloth/ dress 
c. Àda lè kpaȳi Ètùlo

Ada PROG learn Ètulo

Ada is learning Etulo.

$\mathrm{d}$. Ewe mbe òzu ǹgi èta

Ewe build house of three

Ewe built three houses

e. Ò gekè òzû/ èwishî

3SG lean house/wall

$\mathrm{He} / \mathrm{she}$ leans on the house/wall

$\begin{array}{ccc}\text { f.Ò } & \text { bekè } & \text { èwô } \\ \text { 3SG lean } & \text { body }\end{array}$

$\mathrm{He} / \mathrm{she}$ lean on the body

g.O ǹdzì àdishì

3SG bury yam seed

$\mathrm{He} / \mathrm{she}$ planted yam

$\mathrm{h} * \mathrm{O}$ ǹdzì angwo

3SG bury yam

He planted yam

The data available to the study shows that most simple disyllabic verbs comprise CVCV syllable structure. The verbs

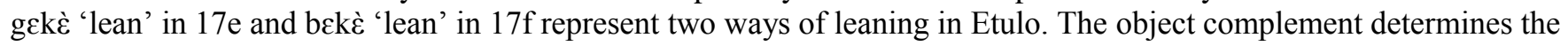
verb that is used in sentential construct. Based on selectional restriction, gekè occurs with -animate object complements while beke occurs with + animate entities, for instance leaning on the human body . The verb ǹdzì 'bury' used in $17 \mathrm{~g}$ can also take ikwô "corpse" as its object complement. The expression in $17 \mathrm{~h}$ does not signify native-like competence in Etulo because angwo 'yam' can be harvested but not planted. This is different from what obtains in other languages, for instance the Igbo language would use the expression so $\mathrm{j} \overline{\mathrm{i}}$ " "plant yam" as well as gwu jī "harvest yam" which implies that ji 'yam' can both be planted and harvested.

\subsection{Complex Verbs}

Under this category, we discuss the verbs that involve a combination of a verb and a noun. The verb and a noun when joined together usually yield a different meaning, which may or may not be linked to either of the component parts. Such verbs are shown in 18a-h below:

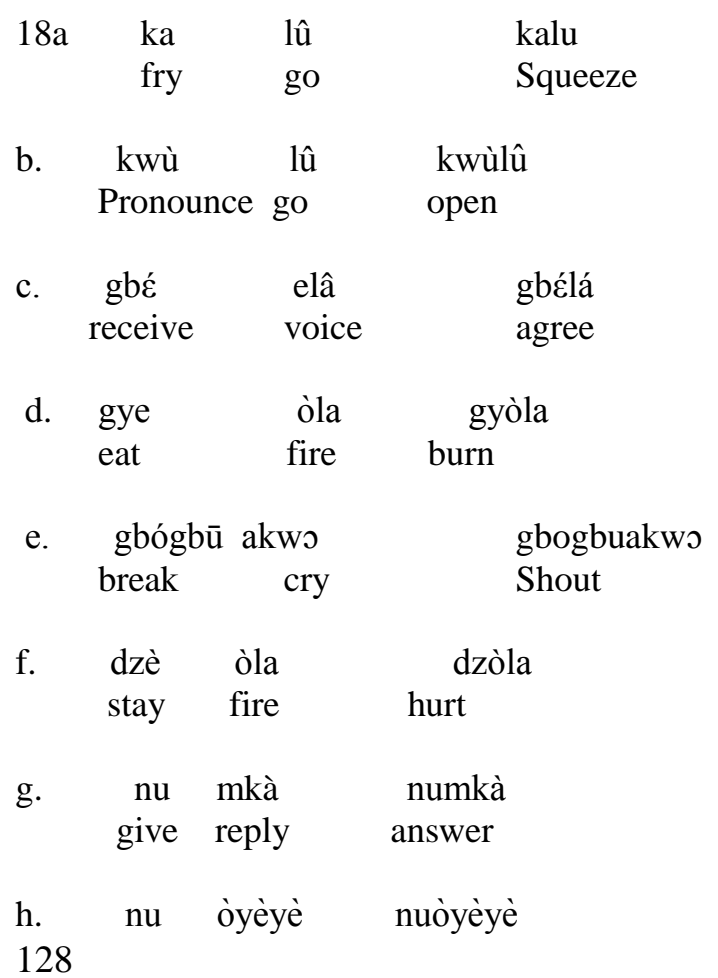


give faith believe

Apart from examples 18a and b where two verbs are joined together to derive a single verb, other examples in $18 \mathrm{c}-\mathrm{h}$ are compound verbs consisting of a verb and a noun. Examples 19a-d comprise sentences instantiating some of the nouns and verbs that make up the compound verbs in isolation. It is observed that they express events in isolation; hence, they have independent meanings.

19a Afe gbe ùdzà mi otsa anî Afe receive money PREP father $1 \mathrm{SG}$

Afe received money from my father

b. ònwè kwu ìyi mgbanî child pronounce name POSS1SG

The child pronounced my name

c. Anì dzè mi Àdì 1SG stay PREP Adi I stay in Adi

d.Efu kyē àyàbà ka Efu take plantain fry Efu fried plantain.

Examples 20a-f shows the combination of either two verbs or a verb and a noun in sentences.

20a Àbo mgbi ani lè dzòla Hand POSS 1SG PROG stayfire My hand is hurting me.

b. j̀d ̀ nê gyòla soup DEM eat/consume (by) fire

The soup got burnt

c.Efu kyē kalu udzà

Efu take squeeze money

Efu squeezed the money

d.O kwūlū ofè

3SG open door

$\mathrm{He} / \mathrm{She}$ opened the door.

e.Èyi gbèlà òkwakyes $\bar{\varepsilon}$

1PL agree to meet

We agreed to meet.

f.Anì nuòyèyè mi Ìmgbigbàshò

1SG believe in God

I believe in God

In 20a, the verb dzòla 'hurt' is a compound verb , which consists of dzè 'stay and òla 'fire' . In fast speech, the first vowel of the noun òla 'fire' assimilates the vowel of the verb dzè 'stay'. The verb burn 'gyòla' in $20 \mathrm{~b}$ is conceived by the native speakers as a case where the subject NP eats fire hence the concatenation of gye 'eat' and òla 'fire'.

\subsection{Conclusion}

In this study, we have tried to show the structure of the Etulo verb. With respect to the syllable structure, the study discovered that the verb in Etulo attests three syllable patterns: namely monosyllabic verbs with a CV structure, disyllabic verbs which have $\mathrm{CV}-\mathrm{CV}$ and $\mathrm{N}-\mathrm{CV}$ structure and trisyllabic verbs with the CV-CV-CV and CV-CV-V structures. Morphologically, Etulo verbs were grouped into simple and complex verbs. Some complex verbs were observed to display variable meanings. Moreover, the study shows traces pointing to co-occurrence restriction between Etulo verbs and their object complements. From the findings of the study, it can be concluded that the Etulo verb structure aligns with the structure attested for the Benue Congo language family in particular and African languages at large. 


\section{References}

Childs, G.T. 2003.An Introduction to African languages. Amsterdan: John Benjamins

Ezenwafor, C.and B. Mmadike .2012. A study of tone and syllable structure in Etulo.in Language ,literature and communication in a dynamic world. A festschrift for Chinyere Ohiri- Aniche. Ozo-mekuri Ndimele (Ed.). Port Harcourt: Grand Orbit Communication. 617-622.

Gordon, R. 2005. Ethnologue. Languages of the world.Texas: SIL http:/www.ethnologue.com.8th November 2016

Green, M and Igwe, G. 1963. A descriptive Grammar of Igbo. London : Oxford University Press

Mbagwu, D. 2013. Locatum and location verbs in Igbo: A morpho-syntactic analysis. Unpublished PhD dissertation, University of Nigeria.

Palmer, F. 1965. A linguistic study of the English verb. London: Longman

Payne, T. 2006. Exploring Language Structure: A student's guide. London: Cambridge University Press.

Welmars, Wm. E. 1973. African Language Structure. London: University of California Press

Yuka, L. and Omoregbe, E.. 2010. The Internal structure of the Edo verb. California Linguistic notes 35(2) 1-19.

Yuka, L. and Agbo, M. 2011.Transitivity and double object construction in Igbo. Journal of West African Languages. XXXVIII (2)33-47.

Yuka, L. and Agbo, M. 2016. The logical structure of the Lamnso verbal component: in Issues in contemporary linguistics.A festschrift for Oladele Awobuluyi. Ozo-mekuri, Ndimele, Yuka L.C and Ilori, J.F (Eds) PortHarcourt: M\&J Grand orbit. 71-82 